
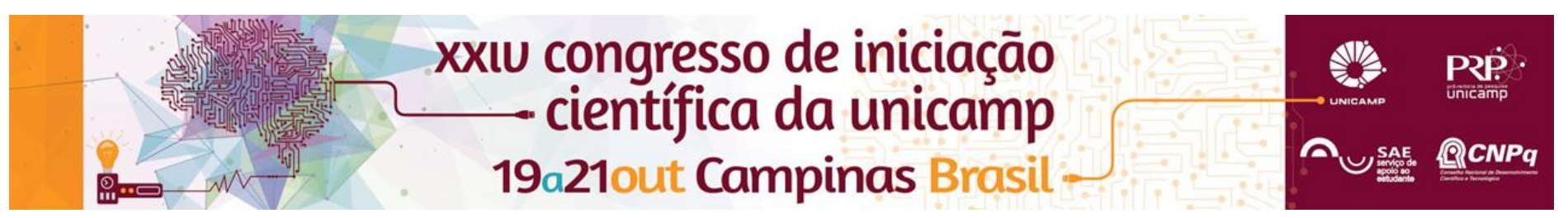

\title{
O Mar de Dorival Caymmi: uma análise semiótica da relação entre voz e violão
}

\section{Lucas T. Madi*, Regina Machado.}

\section{Resumo}

A partir do estudo do LP Canções Praieiras, do cantor e compositor Dorival Caymmi, realizamos a transcrição da canção "O Mar" e posterior análise, tendo como fundamentação teórica e processual a Semiótica da Canção (TATIT) e a Análise do Comportamento Vocal (MACHADO).

\section{Palavras-chave:}

Caymmi, Semiótica, Arranjo

\section{Introdução}

Buscamos analisar a relação entre o violão e a voz de Dorival Caymmi a partir de uma música selecionada do álbum Canções Praieiras, com o intuito de demonstrar as marcas composicionais e interpretativas tecidas no elo entre violão e voz na obra do cancionista. Outro objetivo do trabalho é a absorção dos métodos analíticos desenvolvidos pelos pesquisadores da área da Semiótica da Canção para futuros desdobramentos do projeto.

\section{Resultados e Discussão}

Transcrevemos todas as músicas do álbum Canções Praieiras (1954) para a partitura no modelo "Songbook" e escolhemos "O Mar" para análise mais aprofundada. A partir das transcrições pudemos também traçar um perfil violonístico de Caymmi.

Com base na Semiótica da Canção desenvolvida por Luiz Tatit, bem como nos trabalhos de MACHADO (2012) e COELHO (2007), pudemos analisar como se delineia a relação voz/violão na referida canção.

Para facilitar a análise e conseguir entender a obra como um todo, dividimos a música em três partes: Adagio Inicial, como propõe Risério e Abreu, O Retrato do Mar (A Onda Menor), a História de Pedro e Rosinha (A Onda Maior).

No Adagio Inicial, Caymmi ambienta o ouvinte com a sonoridade da maré simulada pelo violão. $\mathrm{Na}$ onda menor ele introduz o eixo narrativo da terceira parte de maneira breve e sucinta, predominando o regime melódico cancional passional. $\mathrm{Na}$ onda maior ele expõe o drama humano através da levada do samba, predominando o regime melódico tematizado, ele gradualmente cria uma tensão entre 0 discurso linguístico e musical, retornando à passionalização ao final do trecho para deixar clara a tragédia vivida pelo casal Pedro e Rosinha.

O tema principal do mar expressa na letra pelo trecho /O Mar quando quebra na praia é bonito, é bonito.../ é exposto 3 vezes de maneira igual: a primeira precedida da introdução, a segunda retornando ao tom original após a variação meio tom acima da tonalidade (A Onda Menor) e a terceira após o samba (A Onda Maior), fechando a música. Podemos interpretar que o Mar, independentemente da proporção e profundidade das ações do homem (para o próprio homem) sobre suas ondas, será sempre o mesmo em sua magnitude e grandeza. A ação do homem sobre ele é tão efêmera quanto uma onda que quebra na praia.

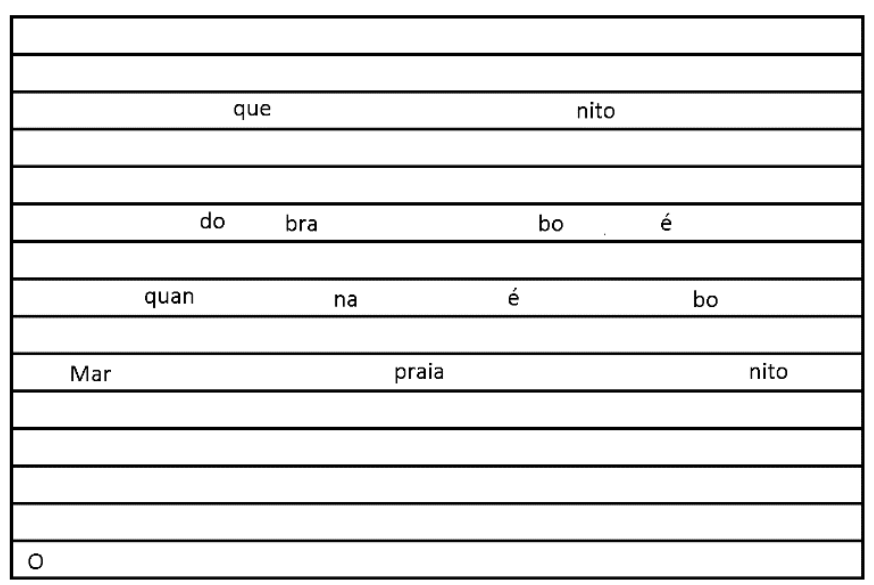

Figura 1. Tema principal do mar em uma tatitura.

\section{Conclusões}

Caymmi tem um violão peculiar e em extrema sintonia com seu gesto vocal, não só nessa música, mas em outras também, visto suas características específicas de afinação. O discurso violonístico presente no arranjo corrobora diretamente o sentido proposto no gesto vocal, principalmente quando há tensionamento entre o plano de conteúdo e o plano de expressão.

\section{Agradecimentos}

Agradeço a orientação da Profa. Dra. Regina Machado e a todos os integrantes de grupo de pesquisa VOX MUNDI pelo apoio e ajuda com as dúvidas surgidas no desenvolvimento do trabalho.

\section{Bibiliografia}

COELHO; M. L. G. O Arranjo como Elemento Orgânico ligado à Canção Popular Brasileira: Uma Proposta de Análise Semiótica. 2007. 226, Tese (Doutorado em Linguística) - Universidade de São Paulo MACHADO, R. Da Intenção ao Gesto Interpretativo: Análise Semiótica do Canto Popular Brasileiro. 2012. 192, Tese (Doutorado em Linguística) - Universidade de São Paulo.

TATIT, L. A. M. O Cancionista: Composição de Canções no Brasil. 2002. 323, Edusp - $2^{\mathrm{a}}$ edição.

Discografia

DORIVAL CAYMMI. Canções Praieras. 1954. Gravadora Odeon, Long Playing 331/3 RPM , 8 faixas. 